Article

\title{
Under the Influence: Advertisers' Impact on the Content of Swiss Free Newspapers
}

\author{
Colin Porlezza \\ IPMZ-Institute of Mass Communication and Media Research, University of Zurich, 8050 Zurich, Switzerland; \\ E-Mail: c.porlezza@ipmz.uzh.ch
}

Submitted: 1 February 2017 | Accepted: 11 March 2017 | Published: 13 April 2017

\begin{abstract}
The study focuses on whether and to what extent advertisers influence the editorial content of free newspapers in the German part of Switzerland. The contribution analyzes, grounded on an historic approach, the most competitive period in Switzerland, 2008, when not less than five freesheets were competing for advertisers and public attention. By using Altmeppen's (2006) organizational theory, the paper offers a theoretical frame able to describe the vanishing co-orientation between the media management and the newsroom, a trend that aggravates commercialization processes in news organizations. In a situation of economic turmoil, so the hypothesis, newsrooms are more inclined to positively adapt the valence of their coverage about their main advertisers in order to keep them in the portfolio. Using a content analysis, the author examined the editorial coverage of six among the most important advertisers of Swiss free newspapers, carrying out an aggregated statistical analysis based on logistic regression. The study revealed that free newspapers with a strong market orientation display a higher chance to publish positive facts and evaluations about advertisers with a high advertising expenditure.
\end{abstract}

\section{Keywords}

advertising; commercialization; free newspapers; journalism; media accountability

\section{Issue}

This article is part of a multidisciplinary issue of Media and Communication, edited by Epp Lauk (University of Jyväskylä, Finland) and Raul Reis (Emerson College, USA).

(C) 2017 by the author; licensee Cogitatio (Lisbon, Portugal). This article is licensed under a Creative Commons Attribution 4.0 International License (CC BY).

\section{Introduction}

Newspapers are confronted with massive financial problems due to their business model still mostly grounded on advertising, which in the present context seems no longer viable. Several scholars argue in fact that newspaper organizations have experienced "severe difficulties because of their historical dependence on advertising notably classified ads as a source of revenue" (Siles \& Boczkowski, 2012, p. 1379; see also Meyer, 2009). The intensifying pressures on media enterprises lead to the assumption that decisions concerning the publication of editorial content are much more frequently taken under the influence of economic principles and not under the perspective of journalistic news values (Esser \& Brüggemann, 2010)-with the risk that media firms may orientate their strategic decisions, also with regard to the se- lection of the editorial content, more on the needs and requests of the advertising industry rather than leave them to journalists. These economic pressures may well tear down the "Chinese Wall" that usually separates the editorial from the commercial part (Schudson, 1978).

This dysfunctional trend is reflected by the increasing use of hybrid advertising formats in newspapers such as advertorials, brand journalism, sponsored content, promotional news and other terms used to describe different marketing tools (Siegert \& Brecheis, 2005). The current issues with regard to hybrid advertising formats are aggravated by the increased use of native advertising in digital news outlets (Porlezza, 2017). However, the redefinition of the rising advertising-editorial divide (Carlson, 2015) is not limited to hybrid forms of advertising. The commercial influence goes well beyond formal aspects and visuals. This leads to what McChesney (2004) 
has labeled as "hyper-commercialization", that is the specific impact of advertisers' pressures and interests onto the journalistic production process in terms of coverage and tone. Although there are some case studies, mostly based on anecdotal evidence, quantitative data on specific markets such as freesheets are rare.

This study aims to go beyond the predominant discourse about hybrid advertising. It wants to shed light on whether and to what extent advertisers influence the editorial content by focusing on free newspapers in the German part of Switzerland. The contribution analyzes, grounded on an historic approach, the most competitive period in the Swiss print media market, 2008, when not less than five free newspapers were competing for advertisers and public attention. This was an exceptional and unique era in the history of the Swiss media market, also because today, only two free newspapers are left. At the time, the enormous economic difficulties due to the financial crisis led not only to a massive decline of advertising revenues, it also increased the competition for advertising between the main media conglomerates.

In this grieve economic situation, so the main hypothesis, newsrooms are more inclined to positively adapt the tone of their coverage about their main advertisers in order to keep them in their portfolio, with dysfunctional consequences for their independence, the transparency as well as the quality of their journalistic content. As a result, the traditional separation between editorial and commercial content is abolished, leading to a biased coverage. Using a quantitative content analysis, the author examined the editorial coverage of six among the most important advertisers (in terms of advertising expenditures) of the free newspapers, carrying out an aggregated statistical analysis based on logistic regression. The study revealed that free newspapers with a strong market orientation display a higher chance to publish positive facts and evaluations about advertisers with a higher advertising expenditure. This phenomenon constitutes a serious challenge for the future of (free) newspapers, because it undermines their credibility and threatens journalistic autonomy in general. The shrinking financial resources that favor the trend to tear down the "Chinese Wall" needs a close scrutiny as well as a critical stance in terms of journalistic norm construction and the development of accountability practices in order to allow journalists to operate independently of commercial pressures and to avoid market-driven information.

\section{The Impact of Advertising on Journalism}

Although in the 1920s scholars like Max Weber and Karl Bücher already condemned the risk of commercialization of the press due to advertising (Kiefer, 2005, p. 20ff.), the discussion about the crumbling "Chinese Wall" was launched in the Anglo-American world between the 1980 s and early 1990s by critical scholars such as Herman and Chomsky (1988), Underwood (1993) or McManus (1994), all of whom referred to different forms of market-driven journalism. However, particularly during the 2000s, researchers such as McChesney (2004) and Croteau and Hoynes criticized the newspaper industry for having followed an economic oriented approach, which "certainly challenges the belief that the unregulated marketplace adequately responds to the public's needs" (2006, p. 30).

The increasing commercialization of the news media is also reflected by a continuous shift in the organizational structures of the news media that favor the implementation of an economic logic in the newsroom. Particularly useful in this regard is the theory presented by Altmeppen (2006), which shows how the partnership between the media management and the newsroom becomes increasingly unbalanced. Ever more often, the management applies pressure on the newsroom by adopting threats such as budget cuts in order to influence the editorial content. This way, the co-orientation between the management and the newsroom becomes uneven, which is why the economic logic of the management overlaps the normative orientation of journalists towards the public interest. Advertising income becomes therefore a dominant factor, as the media management passes on the requests from the advertisers to the newsroom.

Although most empirical research on the interweaving of journalism and advertising concentrates on hybrid advertising formats (see e.g. Bærug \& Harro-Loit, 2012; Carlson, 2015; Eckman \& Lindlof, 2003; Erjavec, 2004; Ferrer Conill, 2016; Harro-Loit \& Saks, 2006; Lewis, Williams, \& Franklin, 2008) or on their effects on consumers (see e.g. Austin \& Newman, 2015; Howe \& Teufel, 2014), a few empirical studies confirm in fact that advertisers' demands are passed on to the newsrooms. Hays and Reisner (1990) discovered that journalists are regularly exposed to the pressure of advertisers. Soley and Craig (1992) endorsed these findings since about 90\% of the surveyed journalists reported that some pressure had been applied to them. In addition, most editors said that the pressure was not coming from the advertisers but directly from within their newspapers, which reflects also Altmeppen's theoretical model presented above. An and Bergen (2007) as well as Nyilasy and Reid (2011) both confirm this impression, demonstrating that advertising directors "are willing to appease their advertisers, and are also willing to positively respond to advertisers requests" (An \& Bergen, 2007, p. 118). This occurs more frequently at smaller, chain owned newspapers than in big and independent papers.

Other studies show that advertising pressure can also cause different forms of complacent journalism. Reuter and Zitzewitz (2006), looking at fund recommendations in financial publications, reveal that they are in fact correlated with advertising expenditures. Rinallo and Basuroy (2009) discover similar relationships, demonstrating that advertising spending influences the media coverage of advertisers. They examined the coverage of 291 Italian fashion companies in 123 publications from Italy, France, 
Germany, the UK and the US. The two authors found that advertising has a strong positive influence on coverage and that publishers, which depend more on a specific industry for their advertising revenues, are susceptible to a higher degree of influence from their corporate advertisers. Gambaro and Puglisi (2009) draw similar conclusions in a study on the daily coverage of listed companies in the Italian press. The two researchers illustrate that newspaper coverage of a given company is positively correlated to the amount of ads purchased by that company.

When it comes to the impact of advertisers on the coverage about them, research is often limited to case studies, frequently based on indirect evidence due to methods such as interviews or surveys (see e.g. Siegert \& Eberle, 2004; or Fassihi, 2008). In addition, results are not always consistent among the different studies, bearing either contradicting findings or small effects. Andresen (2008), analyzing the German magazine Der Spiegel and the newspaper Süddeutsche Zeitung, investigated whether the amount of ad spending was correlated to a more favorable coverage of four advertisers and their products. He found only weak correlations between the two variables. Kolb and Woelke (2010) carried out a study on two Swiss free newspapers and their coverage of a Swiss bank, which advertised only in one of the two papers. The results show that the newspaper without any ads reported more often about the bank and the tenor was far more critical. Based on the previous two analyses, Lagetar and Mühlbauer (2012) did a similar case study scrutinizing the coverage of German and Austrian news outlets about a supermarket chain. In their case, however, the findings were inconsistent, as there were no clear-cut differences between the coverage of those newspapers with and those without advertising from the supermarket.

Based on these reflections, this study poses the following general research question:

RQ: What kind of impact does the ad volume exert on the editorial coverage of advertisers?

Two different premises are related to this question: the higher the advertising volume of an advertising company, the greater the likelihood that they will be able to control the reporting thanks to the interventions of the media management. Large advertising customers are central to the survival of a free newspaper. For this reason, it can be assumed that the newspapers report more positively about important advertisers. On the other hand, print media, in which a company buys little to no advertising, pay less attention to their interests and report more critically, which means that:

$\mathrm{H} 1$ : The larger the ad volume of an advertiser, the greater the chance of a positive coverage with regard to the presented facts.
Likewise, it is possible that the coverage yields positive effects on the judgments made by journalists (and on the selection of quotes from other actors), which may ultimately help to establish a positive frame around advertisers:

$\mathrm{H}$ 2: The larger the ad volume of an advertiser, the greater the probability of positive judgments by journalists and other actors in the articles.

\section{The Swiss Media Market in 2008: The Climax of the Free Newspapers War}

After a very positive decade in the 1980s in terms of profits, in the 1990s in the Swiss press market the number of titles started to shrink dramatically. About a third of all independent newspaper titles disappeared (Fög, 2010). At the same time, the mergers between media companies started to increase. The concentration processes in the print media market continued unimpeded after the turn of the millennium, with the result that the competition between the larger publishing houses grew steadily. In 2001 and particularly in 2002, the economic crisis led to a collapse in display prices, in addition to falling circulation figures, which added up to the pressure on newspapers.

On December 13, 1999, the Norwegian publisher Schibsted launched the first free newspaper, 20 Minuten, in Zurich. For the first time, a free newspaper offered also journalistic content, aiming at the "unproductive" time of commuters between their home and the workplace. While there had already been free newspapers, their structure as well as the news they offered corresponded more to an official house gazette. The launch of daily free newspapers thus marked the beginning of new era in the Swiss press market.

On January 31, 2000, only four weeks after the start of 20 Minuten, the Swedish company Metro International launched Metropol. However, the ill-designed project was doomed to a quick end, and shortly after its second anniversary, the newspaper ceased its publication in 2002. In the meantime, the most important Swiss publisher, Tamedia, acquired 20 Minuten from Schibsted. Over the next three years, 20 Minuten further strengthened its market position. Tamedia also expanded the website and launched a weekend edition of 20 Minuten.

In 2006, another important publishing house, Ringier, entered the free newspaper market, but with a differed concept: Heute ${ }^{1}$ was launched as an evening paper, intended to attract commuters on their way homeavoiding direct competition with Tamedia's 20 Minuten, which was published early in the morning. Parallel to this project, Ringier launched a free special interest newspaper in 2006, Cash Daily, which was oriented at finance and business reporting. However, the distribution was organized differently, because Cash Daily was available at newsstands only, while 20 Minuten and Heute/Blick am Abend had their own newspaper boxes in the streets.

\footnotetext{
${ }^{1}$ In 2007 Ringier wanted to relaunch Heute to strengthen the brand of their main tabloid newspaper Blick. At the end of May 2008 , just before the start of the European Football Championship, Ringier published Heute under its new name Blick am Abend.
} 
In September 2007, the competition in the freemarket market was even further intensified when an independent PR consultant launched another free newspaper called .ch. The new competitor provoked reactions especially at Tamedia. The publisher immediately increased the circulation of 20 Minuten. Shortly thereafter, in December 2007, Tamedia launched another free newspaper called NEWS, which should be distributed in the same areas as .ch. Although NEWS appeared as a sober journalistic product, it was clearly a product used to assure the dominance of Tamedia in the free commuter newspaper market. 2008 was therefore the culmination point of the free newspaper competition in the Swiss print media market.

Although .ch underwent a re-launch in October 2008, the financial problems of the title did not cease. Hence, the project was abandoned after only one and a half years of existence in May 2009. Seven months later, in December 2009, Tamedia withdrew NEWS from the market. A couple of months before, in March, they had already closed down Cash Daily following a steady decline in advertisement income. This marked the end of a long and hard competition for the free newspaper market in the German-speaking part of Switzerland, which consolidated the image of Switzerland as a stronghold for freesheets. It was by far one of the fiercest battles for market shares on the Swiss print media market and characterized a unique era. Today, with 20 Minuten and Blick am Abend, only two free newspapers survived. By sharing the commuter streams in the morning and during the evening, they do not get in the way of each other, which allows for an apparent peaceful cohabitation. After the free newspaper war ended nearly ten years ago, the print media markets in urban areas such as Zurich continued to be consolidated, also because 20 Minuten and Blick am Abend have become cash cows for the two publishing companies, given that they absorb a considerable amount of advertising within the press market. ${ }^{2}$

\section{Method}

The research design to determine an advertiser influence on the journalistic coverage included a two-step methodological process on a sample of five freesheets (20 Minuten, Heute, Cash Daily, .ch and NEWS) and, as an object of comparison, one paid-for newspaper (TagesAnzeiger): (1) a content analysis that was necessary to determine the advertising volume for each advertiser, (2) another content analysis in order to investigate the journalistic coverage of selected advertisers in terms of the valence.

Since it was not possible to obtain specific advertising data for each newspaper it was necessary to carry out a content analysis to establish the advertising vol- ume of each major advertiser. The analysis included three natural weeks between February 18, 2008 and March 7, 2008. The analysis included advertisements out of the five most ad-intensive markets with regard to the newspaper sector: retailers, car/automotive business, banks/insurances, telecommunication/mobile and electronics $/ \mathrm{IT}^{3}$ Besides that, four more sub-markets were included, where the hybridization between the editorial and commercial content was expected to be strong: cosmetics, jewelry/watches/accessories, clothing, tourism, and public transport. The study included a total of 912 advertisements.

In order to avoid distortions due to the different page sizes of the newspapers, the study converted the aggregated advertising area into an index, so that the advertising volumes are directly comparable. This advertising index $(A l)$ is calculated as follows:

$$
A I=\Sigma F_{A} / F_{P S}
$$

$\sum F_{A}$ designates the total surface of a company's advertising, while $F_{P S}$ indicates the page size of a newspaper. This is calculated from the height and width of the printable surface. By dividing the entire advertising surface of a company through the page size, one gets an advertising index Al. This index served not only as a basis for comparisons in terms of advertising volumes between the newspapers, but also as a starting point for the calculations regarding the influence of advertisers.

The second content analysis focused on a different unit of analysis: articles about selected advertisers. All kinds of editorial contributions such as news reports, comments or features were included, but not letters from the readers or other contributions from third parties. The analysis focused on the valence, which was assessed on the basis of a five-step scale ranging from 1 (unrestricted negative) to 5 (unrestricted positive). The intermediate expression $(=3$ ) stands for a balanced, but also for an ambivalent reporting, in which both negative and positive arguments occur in the same way. According to the method of Kolb and Woelke (2010), balanced or ambivalent articles were omitted for the statistical calculations. Only articles that do express either a positive or a negative valence are included. The evaluative aspects play a decisive role not only in the overall assessment of the companies. They are also relevant when it comes to the specific statistical analysis of logistic regression, which requires a dichotomous dependent variable such as positive and negative facts or evaluations.

The period of analysis corresponds to the three weeks from the first content analysis. In order to include reporting that preceded as well as succeeded the advertising campaigns recorded during the period of observation, the analysis of the editorial coverage added another week before and one after the period of the advertising

\footnotetext{
20 Minuten, with a circulation of 442,994, is the most read newspaper in Switzerland, Blick am Abend with a circulation of 270,894 is ranked number two (Schweizer Medien, 2016).

${ }^{3}$ The selection of the different industries was made on the grounds of Nielsen Media/Media Focus that publishes data about the most important advertising industries in Switzerland.
} 
analysis. This means that the period of investigation for the second content analysis covers five weeks and ranges from February 11, 2008, to March 14, 2008. The reason to use natural weeks instead of artificial weeks is relevant, because it allows a continuous observation of advertising campaigns as well as the reporting. This might result in an overrepresentation of certain companies in the coverage due to specific events, but the synchronous analysis of different news outlets allows to control for biases in the coverage, since all newspapers are confronted with the same events (Andresen, 2006).

The second content analysis included companies from the following sectors only: retailers, banks, the telecommunications and mobile industry as well as public transport. The selection was made on the data collected in the first study. The selected companies were the ones with the highest advertising volumes. Table 1 shows the specific companies.

It has to be said that the chosen method does not allow to make any statements as to whether the presumed influence from the advertisers occurs directly or indirectly. The results only show whether there is an influence, not how it comes about. Consequently, the results cannot serve as a response to the question of whether there are any collusions between the management and the journalistic staff regarding the overall reporting strategy.

\section{Results}

The data set of the content analysis with regard to the coverage of the advertisers includes a total of 889 articles. In the five weeks under review, 227 articles belong to the Tages-Anzeiger, 193 to Cash Daily, 152 to NEWS, 120 to 20 Minuten, 105 to Heute and 92 to .ch. The differences in the number of articles are mainly due to three factors. First, the Tages-Anzeiger has a larger page size than the freesheets and offers therefore room for more contributions. In addition, it also offers the highest num- ber of pages, which makes it possible to report more extensively about a company. The second reason is related to Cash Daily: as a newspaper specialized in financial and business news, the paper focuses more often on the companies in the sample, particularly on the two banks, and reports more frequently about events that do not end up in the other newspapers. A third reason is related to the different market orientation of the newspapers: Particularly 20 Minuten and Heute apply a tabloid style of journalism, which emphasizes subjects like entertainment, sports, style, fashion, celebrities and gossip. The clear focus on soft news rather than on traditional journalistic themes like politics and economy lets both paper appear as more market-driven compared to the other papers in the sample. Moreover, 20 Minuten did not produce its own business section at that particular time, but they got the content from and external agency.

Table 2 shows that the newspapers often reported on the two banks UBS (282 articles) and Credit Suisse (165). The high number of articles on the two Swiss banks is related to the banking and economic crisis at that time. At the beginning of 2008, both banks were under public scrutiny due to the turmoil on the American mortgage market.

In order to analyze the relationship between the ad volume and the valence of the coverage about certain advertisers, logistic regression was chosen as a means of statistical analysis. Unlike linear regression, it does not provide estimates of expected values, but attempts to determine the probability of a specific outcome (Backhaus, Erichson, Plinke, \& Weiber, 2003; Hosmer \& Lemeshow, 2000). The logistic regression considers therefore the socalled odds. These reflect the probability for an event to happen, relative to the probability that the event does not occur. With regard to the presented study, the logistic regression considers the probability of a positive coverage compared to a negative outcome. The interpretation of the data is based on the odds ratio, which

Table 1. Sample of most important advertisers.

\begin{tabular}{llll}
\hline Retail & Banks & Telecommunications & Public transport \\
\hline Migros & UBS & Swisscom & SBB \\
Coop & Credit Suisse & & \\
\hline
\end{tabular}

Table 2. Number of articles about the selected advertisers.

\begin{tabular}{lrrrrrrr}
\hline & Migros & Coop & UBS & CS & Swisscom & SBB & Total \\
\hline 20 Minuten & 7 & 9 & 46 & 20 & 9 & 29 & 120 \\
Heute & 16 & 13 & 17 & 13 & 22 & 24 & 105 \\
ch & 10 & 3 & 29 & 21 & 5 & 24 & 92 \\
Cash Daily & 16 & 16 & 71 & 51 & 21 & 18 & 193 \\
NEWS & 11 & 10 & 57 & 28 & 6 & 40 & 152 \\
Tages-Anzeiger & 37 & 21 & 62 & 32 & 76 & 62 & 227 \\
\hline Total & 97 & 72 & 282 & 165 & & 797 \\
\hline
\end{tabular}

Notes: Basis: February 11, 2008-March 14, 2008, n = 889 . 
indicates how much more likely a particular event occurs based on the degree of the independent variable. In other words: the odds ratio in this particular study indicates the chance of a positive coverage to the extent to which the advertising pages are increased by one unit. Obviously, this is only true if all other variables are kept constant. The study also controls for potentially interfering variables, such as the revenue of the advertiser or the penetration of the news outlet.

\subsection{The Influence of Advertisers on Presented Facts}

The central hypothesis of the study states that advertisers with a high advertising volume influence the reporting on their companies in a positive way. In other words, the higher the advertising expenditure of an advertiser, the greater the chance that the coverage will be positive. The analysis of the reporting took place on the grounds of two different dimensions: presented facts and evaluations from journalists and other actors.

The first dimension focuses on the valence of the presented facts. The coding is based on the presented facts only, not the judgements, allowing thus for a general assessment of the reporting. The balance between the number of positive and the negative facts determines how the general factual situation in the article is to be coded. For example, if an article contains the information that a bank has lost money due to an erroneous investment strategy, the element is coded as a negative fact. If an article contains for instance one positive fact and three negative facts, the article will be coded as overall negative. Table 3 shows the aggregated analysis for all free newspapers, for the two market-oriented papers 20 Minuten and Heute, and for the paid-for newspaper Tages-Anzeiger.

In the aggregated analysis the results reveal that there is a small but nonetheless significant chance that free newspapers in general, and the two market-oriented papers in particular, offer more positive facts if the ad volume grows. However, there is basically no difference between the aggregated free newspapers and the two market-oriented newspapers, which might imply that the two free newspapers that offer more soft news are having a specific effect on the aggregated analysis. The paidfor newspaper does not show any significant relation between the ad volume and the valence of the coverage about the advertisers. Neither the revenue of the advertisers nor the penetration of the newspapers have an impact on the presented facts.

When it comes to the analysis of the individual titles, there are clear differences (see Table 4): particularly Heute with an odds ratio of 2.16 and 20 Minuten with 1.08 show a higher chance of a positive coverage of their main advertisers. In other words: advertisers in Heute have more than twice the chance of getting related to positive facts if they increase their ad volume by one page. No other free paper shows significant results. This actually confirms the above mentioned thesis that the probability to get a positive coverage is so high for Heute-and to a lesser degree for 20 Minuten - that the two market-oriented papers alone determine the aggregated analysis for all free newspapers.

\subsection{The Influence of Advertisers on Journalists' Evaluations}

The second dimension is based on the statements and evaluations of journalists and other actors mentioned in the articles about the companies in the sample. This dimension is used in order to shed light on how journalists personally-and through quotes of other peopleassess the events. The coding process is carried out the exact same way as for the first dimension of the presented facts. While the selection of the presented facts may be more strongly influenced by the actual event, for instance due to a chronological narration of the different events that happened up to that particular moment, the judgements made by journalists and other people allow for a clearer account of the journalistic production process in relation to an advertiser.

The aggregated analysis of the evaluations made by journalists reveals that free newspapers in general, and

Table 3. Aggregated model for presented facts.

\begin{tabular}{|c|c|c|c|c|c|c|c|c|c|}
\hline \multirow[b]{2}{*}{ Predictor } & \multicolumn{3}{|c|}{ All free newspapers } & \multicolumn{3}{|c|}{$\begin{array}{l}\text { Market oriented newspapers } \\
20 \text { Minuten \& Heute }\end{array}$} & \multicolumn{3}{|c|}{$\begin{array}{l}\text { Paid-for newspaper } \\
\text { Tages-Anzeiger }\end{array}$} \\
\hline & $B$ & $S E B$ & $e^{B}$ & $B$ & SE B & $e^{B}$ & $B$ & $S E B$ & $e^{B}$ \\
\hline Ad volume & $0.11^{* *}$ & 0.01 & 1.11 & $0.10 * *$ & 0.03 & 1.11 & 0.01 & 0.01 & 1.11 \\
\hline News media (penetration) & 0.00 & 0.00 & 1.00 & $-0.01 * *$ & 0.00 & 0.99 & -0.12 & 0.15 & 0.89 \\
\hline Advertiser (revenue) & 0.00 & 0.00 & 1.00 & 0.00 & 0.00 & 1.00 & 0.00 & 0.00 & 1.00 \\
\hline Constant & -0.41 & 0.28 & & 0.56 & 0.49 & & 55.21 & 71.71 & \\
\hline Nagelkerke $\mathrm{R}^{2}$ & & 0.07 & & & 0.22 & & & 0.16 & \\
\hline $\mathrm{n}$ & & 372 & & & 133 & & & 115 & \\
\hline$\%$ correct predicted cases & & 68.8 & & & 69.9 & & & 73.9 & \\
\hline
\end{tabular}

Notes: $B=$ Regression coefficient, $S E B=$ Standard error, $e^{B}=$ Odds Ratio (95\% confidence interval), Nagelkerke $\mathrm{R}^{2}=$ explained variance, $* * p<.01$. 
Table 4. Individual model with regard to the presented facts.

\begin{tabular}{|c|c|c|c|c|c|c|c|c|c|c|c|c|c|c|c|}
\hline \multirow[b]{2}{*}{ Predictor } & \multicolumn{3}{|c|}{20 Minuten } & \multicolumn{3}{|c|}{ Heute } & \multicolumn{3}{|c|}{.$c h$} & \multicolumn{3}{|c|}{ Cash Daily } & \multicolumn{3}{|c|}{ NEWS } \\
\hline & $B$ & $S E B$ & $e^{B}$ & $B$ & $S E B$ & $e^{B}$ & $B$ & $S E B$ & $e^{B}$ & $B$ & $S E B$ & $e^{B}$ & $B$ & $S E B$ & $e^{B}$ \\
\hline Ad volume & $0.08 * *$ & 0.04 & 1.08 & $0.77 * *$ & 0.63 & 2.16 & -2.37 & 1.46 & 0.09 & -0.67 & 0.37 & 0.51 & -0.31 & 0.26 & 0.74 \\
\hline $\begin{array}{l}\text { Advertiser } \\
\text { (revenue) }\end{array}$ & 0.00 & 0.00 & 1.00 & 0.00 & 0.00 & 1.00 & 0.00 & 0.00 & 1.00 & 0.00 & 0.00 & 1.00 & 0.00 & 0.00 & 1.00 \\
\hline Constant & -0.29 & 0.58 & & -2.01 & 2.06 & & 1.28 & 1.65 & & 0.72 & 0.65 & & -0.49 & 0.91 & \\
\hline Nagelkerke $\mathrm{R}^{2}$ & & 0.17 & & & 0.29 & & & 0.09 & & & 0.07 & & & 0.03 & \\
\hline $\mathrm{n}$ & & 74 & & & 59 & & & 49 & & & 98 & & & 92 & \\
\hline $\begin{array}{l}\% \text { correct } \\
\text { predicted } \\
\text { cases }\end{array}$ & & 71.6 & & & 69.0 & & & 79.6 & & & 65.3 & & & 72.8 & \\
\hline
\end{tabular}

Notes: $B=$ Regression coefficient, $S E B=$ Standard error, $e^{B}=$ Odds Ratio (95\% confidence interval), Nagelkerke $\mathrm{R}^{2}=$ explained variance,

** $p<.01$. The penetration is missing because in the individual analysis it becomes a constant.

market-oriented freesheets in particular, show a significant chance to offer more favorable judgements about advertisers with higher ad volumes (see Table 5). On the other hand, the revenue of the advertiser, which is an indicator of its absolute market power, exerts no influence on the probability of a positive evaluation. However, the results with regard to the paid-for newspaper Tages-Anzeiger are surprising: the penetration seems to be a significant determining factor of the reporting. An odds ratio of 0.62 means that with a higher penetration of the newspaper, the likelihood of positive evaluations decreases. Accordingly, the probability of a positive evaluation of a company decreases by $38 \%$, per thousand readers. This result-which is in line with what Reimann and Kreibe (2012) found out in a similar case studycould be explained by the fact that newspapers with a different business model based on advertising and subscriptions, are more resistant to pressures from the advertisers. Although the relation is flagged as significant, the result has to be interpreted with caution, since the standard error with respect to the parameter estimate is very large.
The individual media analysis shows one clear result: that chance to be positively judged by journalists in Heute is more than three times higher for an additional ad page $\left(e^{B}=3.43\right)$ than in any other newspaper (see Table 6). The likelihood of a positive assessment is so high that it influences the aggregated analysis for the two market-oriented newspapers $\left(e^{B}=1.79\right)$. However, in the case of journalistic evaluations, there are no other factors that might significantly influence the chances to improve the evaluations.

Overall it can be said that additional ad pages for free newspapers increase the chance for a positive rating. However, this effect is limited to freesheets like 20 Minuten and Heute with a strong market-orientation and with a tabloid style of journalism that strongly focuses on topics of human interest such as entertainment, sports, celebrities and gossip. In the paid-for newspaper, no effect could be observed, which means that the advertising volume in news outlets such as the Tages-Anzeiger does not seem to have any impact on the journalistic production process at all. Due to the fact that both analyses display a significant influence of the advertising vol-

Table 5. Aggregated model for journalists' evaluations.

\begin{tabular}{|c|c|c|c|c|c|c|c|c|c|}
\hline \multirow[b]{2}{*}{ Predictor } & \multicolumn{3}{|c|}{ All free newspapers } & \multicolumn{3}{|c|}{$\begin{array}{l}\text { Market oriented newspapers } \\
20 \text { Minuten \& Heute }\end{array}$} & \multicolumn{3}{|c|}{$\begin{array}{l}\text { Paid-for newspaper } \\
\text { Tages-Anzeiger }\end{array}$} \\
\hline & $B$ & SE B & $e^{B}$ & $B$ & SE B & $e^{B}$ & $B$ & $S E B$ & $e^{B}$ \\
\hline Ad volume & $0.24 * *$ & 0.10 & 1.27 & $0.58^{* *}$ & 0.31 & 1.79 & -0.01 & 0.19 & 0.99 \\
\hline News media (penetration) & 0.00 & 0.00 & 1.00 & 0.00 & 0.00 & 0.99 & $-0.48 *$ & 0.21 & 0.62 \\
\hline Advertiser (revenue) & 0.00 & 0.00 & 1.00 & 0.00 & 0.00 & 1.00 & 0.00 & 0.00 & 1.00 \\
\hline Constant & -1.49 & 0.46 & & -2.34 & 1.38 & & 231.88 & 102.96 & \\
\hline Nagelkerke $\mathrm{R}^{2}$ & & 0.08 & & & 0.27 & & & 0.53 & \\
\hline $\mathrm{n}$ & & 220 & & & 67 & & & 75 & \\
\hline $\mathrm{s} \%$ correct predicted cases & & 71.8 & & & 71.6 & & & 89.3 & \\
\hline
\end{tabular}

Notes: $B=$ Regression coefficient, $S E B=$ Standard error, $e^{B}=$ Odds Ratio (95\% confidence interval), Nagelkerke $\mathrm{R}^{2}=$ explained variance, $* * p<.01$. 
Table 6. Individual model with regard to journalists' and quoted evaluations.

\begin{tabular}{|c|c|c|c|c|c|c|c|c|c|c|c|c|c|c|c|}
\hline \multirow[b]{2}{*}{ Predictor } & \multicolumn{3}{|c|}{20 Minuten } & \multicolumn{3}{|c|}{ Heute } & \multicolumn{3}{|c|}{.ch } & \multicolumn{3}{|c|}{ Cash Daily } & \multicolumn{3}{|c|}{ NEWS } \\
\hline & $B$ & $S E B$ & $e^{B}$ & $B$ & $S E B$ & $e^{B}$ & $B$ & $S E B$ & $e^{B}$ & $B$ & $S E B$ & $e^{B}$ & $B$ & $S E B$ & $e^{B}$ \\
\hline Ad volume & 0.05 & 0.05 & 1.05 & $1.23^{*}$ & 1.00 & 3.43 & -8.43 & 7.58 & 0.00 & 0.35 & 0.46 & 1.42 & -0.27 & 0.50 & 0.77 \\
\hline $\begin{array}{l}\text { Advertiser } \\
\text { (revenue) }\end{array}$ & 0.00 & 0.00 & 1.00 & 0.00 & 0.00 & 1.00 & 0.00 & 0.00 & 1.00 & 0.00 & 0.00 & 1.00 & 0.00 & 0.00 & 1.00 \\
\hline Constant & -0.75 & 0.87 & & -4.66 & 3.55 & & 8.67 & 9.90 & & -1.05 & 0.80 & & -1.56 & 1.98 & \\
\hline Nagelkerke $\mathrm{R}^{2}$ & & 0.04 & & & 0.33 & & & 0.31 & & & 0.01 & & & 0.05 & \\
\hline $\mathrm{n}$ & & 40 & & & 28 & & & 33 & & & 69 & & & 51 & \\
\hline $\begin{array}{l}\% \text { correct } \\
\text { predicted } \\
\text { cases }\end{array}$ & & 70.0 & & & 67.9 & & & 84.8 & & & 65.2 & & & 80.4 & \\
\hline
\end{tabular}

Notes: $S E B=$ Standard error, $e^{B}=$ Odds Ratio (95\% confidence interval), Nagelkerke $\mathrm{R}^{2}=$ explained variance, ${ }^{* *} p<.05$. The penetration is missing because in the individual analysis it becomes a constant.

ume on the chance of a positive reporting in terms of facts and evaluations, both hypotheses $\mathrm{H} 1$ and $\mathrm{H} 2$ areat least in relation to market-oriented freesheets such as 20 Minuten and Heute-partially confirmed.

\section{Discussion and Conclusion}

The trend towards profitability and efficiency is related to a wide-ranging commercialization process in the media. As a result, there is a growing tension between economic and journalistic interests. Market relations exert a greater pressure on media firms, in particular the advertising industry, as it remains the main financial source for most news outlets-especially for freesheets. The study's central finding is therefore sobering: marketoriented free newspapers, financed exclusively by advertising, display a higher chance to positively report about advertisers if their ad volume increases.

The increasing focus on the interests of advertisers and the hybridization between advertising and editorial content are additional signs of commercialization, because they show that business-related factors rule over journalistic autonomy. If free newspapers-like in Switzerland-belong to larger media conglomerates that publish traditional paid-for newspapers as well, the two papers must be positioned in different market segments in order to reduce the risk of cannibalization. This means, that (the remaining) free newspapers may evolve even further into journals that favor topics of human interest. Newspaper content, especially in free sheets, is designed to appeal to specific target groups-young commuterswhose attention can be sold to advertisers. This leads not only to a homogenization of the content, but it favors a continuous hybridization between advertising and editorial content-not surprisingly Blick am Abend was the first newspaper outlet to offer native advertising on its webpage. The co-orientation between journalists and the management described by Altmeppen (2006) becomes therefore increasingly undermined, with consequences that point directly to the heart of journalis- tic professionalism: younger journalists working in Swiss free newspapers are not primarily interested in the public interest, but in the economic wellbeing of the news outlet they are working for (Keel, 2011, p. 242).

Despite all the indicators, which point to a certain impact of the advertising expenditures, there are clear limits to it. The results of the individual analyses underscore this conclusion, since there is no general effect on newspapers. News outlets, which are committed to quality journalism, such as .ch or the Tages-Anzeiger, show no signs of influence. However, the prerequisite for such a result is an ongoing discourse on topics related to journalistic standards and professionalism within the news organization (both in the newsroom and the management). This might well increase the awareness of the positive effects of self-regulatory practices such as codes of ethics, guidelines or ombudsmen (Eberwein \& Porlezza, 2016). The association of private Swiss media companies, Swiss Media, together with different associations from the advertising industry, have thus established a Code of Conduct, declaring that all actors-editors, publishers and advertisers-abide to the principle of transparency. All actors have to make it clear what kind of content is paid for (Swiss Media, 2016).

However, setting up self-regulating practices guaranteeing transparency is not enough. While (self-) regulatory practices may be able to uphold the "Chinese Wall" between editorial and commercial contents on a formal or visual basis, it becomes difficult to oppose economic influences that permeate the journalistic production process as presented in this study: "what strength do the judicial and self-regulatory systems have to maintain journalism as independent and as controller of both political and economic power?" (Svensson, 2016, p. 116). It takes both journalists and the media management to establish a new culture of accountability within the newsrooms. This is essential, as newsrooms are the main place where accountability and self-regulatory measures do have an impact, especially in countries where journalists' unions are not as strong as in Central and Northern Eu- 
rope: "If media managers actively implemented accountability and transparency mechanisms, they could clearly demonstrate that they care for media accountability...." (Fengler, Eberwein, Mazzoleni, Porlezza, \& Russ-Mohl, 2014 , p. 268). By doing so, news organizations would also show that they actually care about their credibility, particularly in times when public trust in the media is waning in the wake of fake news and alternative news media outlets popping up everywhere.

This study helps to establish a broader approach to assessing the advertising pressure on (free) newspapers and expanding the scope of inquiry beyond a single case study and the discourse of hybrid advertising. However, this study also presents some limitations, which in turn are opportunities for further research. First, the content analysis was carried out in relation to a very specific moment in the history of the Swiss print media market. It would be interesting to see whether the impact of the advertisers, with only the two market-oriented free newspapers still on the market, is still intact. Over the last nearly ten years, the structure of the media system has changed and the market has become even more concentrated. Second, a follow-up study could focus on the question whether there are any differences between free sheets and traditional newspapers. Future research should also include other countries. Third, advertising expenditures had to be calculated by way of advertising space, as media organizations did not provide the relevant data.

In conclusion, more is at stake than the credibility of the media. As economic pressures become stronger and shape media content, will journalism still be capable of holding the powerful to account if the public service mission is no longer a central notion of journalism? Is journalism still able to legitimize its own work if journalists' professional role-conception shifts towards commercial interests, producing continuously ethical issues? If the answer is no, it will be rather difficult for journalism to rethink itself (see Peters \& Broersma, 2016) bearing in mind the massive economic and digital challenges awaiting to be tackled.

\section{Conflict of Interests}

The author declares no conflict of interests.

\section{References}

Altmeppen, K.-D. (2006). Journalismus und Medien als Organisationen. Leistungen, Strukturen und Management. Wiesbaden: VS Verlag für Sozialwissenschaften.

An, S., \& Bergen, L. (2007). Advertiser pressure on daily newspapers. A survey of advertising sales executives. Journal of Advertising, 36(2), 111-121.

Andresen, N. (2008). Der Einfluss von Anzeigenkunden auf die redaktionelle Berichterstattung in der Qualitätspresse. Alles Lüge oder offenes Geheimnis? Fachjournalist, 4, 21-26.
Austin, S., \& Newman, N. (2015). Attitudes to sponsored and branded content (native advertising) (Digital News Report 2015). Oxford: Reuters Institute for the Study of Journalism.

Backhaus, K., Erichson, B., Plinke, W., \& Weiber, R. (2003). Multivariate Analysemethoden. Eine anwendungsorientierte Einführung. Berlin and Heidelberg: Springer.

Bærug, J. R., \& Harro-Loit, H. (2012). Journalism embracing advertising as traditional journalism discourse becomes marginal. Journalism Practice, 6(2), 172-186.

Carlson, M. (2015). When news sites go native: Redefining the advertising-editorial divide in response to native advertising. Journalism, 16(7), 849-865.

Croteau, D., \& Hoynes, W. (2006). The business of media. Corporate media and the public interest. Thousand Oaks, CA: Pine Forge Press.

Eberwein, T., \& Porlezza, C. (2016). Both sides of the story. Communication ethics in mediatized worlds. Journal of Communication, 66(2), 328-342.

Eckman, A., \& Lindlof, T. (2003). Negotiating the gray lines: An ethnographic case study of organizational conflict between advertorials and news. Journalism Studies, 4(1), 65-77.

Erjavec, K. (2004). Beyond advertising and journalism: Hybrid promotional news discourse. Discourse \& Society, 15(5), 553-578.

Esser, F., \& Brüggemann, M. (2010). The strategic crisis of German newspapers. In D. Levy \& R. Nielsen (Eds.), The changing business of journalism and its impact on democracy (pp. 39-54). Oxford: Reuters Institute for the Study of Journalism.

Fassihi, F. F. (2008). Werbebotschaften aus der Redaktion? Journalismus im Spannungsfeld zwischen Instrumentalisierung und Informationsauftrag. Konstanz: UVK.

Fengler, S., Eberwein, T., Mazzoleni, G., Porlezza, C., \& Russ-Mohl, S. (2014). Summary: Perspectives for newsrooms, policy-makers and journalism educators. In S. Fengler, T. Eberwein, G. Mazzoleni, C. Porlezza, \& S. Russ-Mohl (Eds.), Journalists and media accountability: An international study of news people in the digital age (pp. 265-288). New York, NY: Peter Lang.

Ferrer Conill, R. (2016). Camouflaging church as state: An exploratory study of journalism's native advertising. Journalism Studies, 17(7), 1-11.

Fög. (2010). Jahrbuch 2010-Qualität der Medien. FögResearch Institute for the Public Sphere and Society. Basel: Schwabe.

Gambaro, M., \& Puglisi, R. (2009). What do ads buy? Daily coverage of listed companies on the Italian press (Working Paper n. 2009-36). Milan: University of Milan.

Harro-Loit, H., \& Saks, K. (2006). The diminishing border between advertising and journalism in Estonia. Journalism Studies, 7(2), 312-322.

Hays, R. G., \& Reisner, A. E. (1990). Feeling the heat from advertisers: Farm magazine writers and ethical pressure. Journalism Quarterly, 67(4), 936-942. 
Herman, E. S., \& Chomsky, N. (1988). Manufacturing consent. The political economy of the mass media. New York, NY: Vintage Books.

Hosmer, D. W., \& Lemeshow, S. (2000). Applied logistic regression. New York, NY: John Wiley.

Howe, P., \& Teufel, B. (2014). Native advertising and digital natives: The effects of age and advertisement format on news website credibility judgments. International Symposium on Online Journalism \#ISOJ, 4(1), 78-90.

Keel, G. (2011). Journalisten in der Schweiz: eine Berufsfeldstudie im Zeitverlauf. Konstanz: UVK.

Kiefer, M.-L. (2005). Medienökonomik. Einführung in eine ökonomische Theorie der Medien. Munich and Vienna: Oldenbourg.

Kolb, S., \& Woelke, J. (2010). Einfluss von Werbekunden auf redaktionelle Inhalte-Quasi-experimentelle Modellierung und empirische Erhebung. Studies in Communication Sciences, 10(2), 51-77.

Lagetar, M., \& Mühlbauer, C. (2012). Skandalös zurückgehalten? Berichterstattung über Werbekunden am Beispiel des Lidl-Bespitzelungsfalles. In S. Gadringer, S. Kweton, J. Trappel, \& T. Vieth (Eds.), Journalismus und Werbung (pp. 167-189). Wiesbaden: Springer VS.

Lewis, J., Williams, A., \& Franklin, B. (2008). A compromised fourth estate? Journalism Studies, 9(1), 1-20.

McChesney, R. (2004). The problem of the media: U.S. communication politics in the 21st century. New York, NY: Monthly Review Process.

McManus, J. H. (1994). Market-driven journalism. Let the citizen beware? Thousand Oaks, CA: Sage.

Meyer, P. (2009). The vanishing newspaper: Saving journalism in the information age. Columbia, MO: University of Missouri Press.

Nyilasy, G., \& Reid, L. N. (2011). Advertiser pressure and the personal ethical norms of newspaper editors and ad directors. Journal of Advertising Research, 51(3), 538-551.

Peters, C., \& Broersma, M. (Ed.). (2016). Rethinking journalism again: Societal role and public relevance in a digital age. London: Routledge.

Porlezza, C. (2017). Digitaler Journalismus zwischen News und Native Advertising. Risiken und Nebenwirkungen einer heiklen Beziehung. In W. A. Meier (Ed.), Abbruch-Umbruch-Aufbruch: Globaler Me- dienwandel und lokale Medienkrisen (pp. 249-270). Baden-Baden: Nomos.

Reimann, A., \& Kreibe, F. (2012). Mass genommen! Das Volumenverhältnis von Redaktion \& Werbung in Zeitungen. In S. Gadringer, S. Kweton, J. Trappel, \& T. Vieth (Eds.), Journalismus und Werbung (pp. 101121). Wiesbaden: Springer VS.

Reuter, J., \& Zitzewitz, E. (2006). Do ads influence editors? Advertising and bias in the financial media. Quarterly Journal of Economics, 121, 197-227.

Rinallo, D., \& Basuroy, S. (2009). Does advertising spending influence media coverage of the advertiser? Journal of Marketing, 73, 3-46.

Schudson, M. (1978). Discovering the news. New York, NY: Basic Books.

Schweizer Medien. (2016). Tageszeitungen und Sonntagszeitungen 2016. Retrieved from http://www. schweizermedien.ch/SCHM/media/SCHMMediaLib rary/Statistiken/Statistiken\%202016_1/16_Tageszei tungen-Sonntagszeitungen-2016_1.pdf

Siegert, G., \& Brecheis, D. (2005). Werbung in der Medien- und Informationsgesellschaft. Wiesbaden: VS Verlag für Sozialwissenschaften.

Siegert, G., \& Eberle, S. (2004). Kommerzialisierung der Kommunikation: Die Werbebranche der Schweiz und die Hybridisierung der Kommunikationsangebote. Medienwissenschaft Schweiz, 2, 13-18.

Siles, I., \& Boczkowski, P. J. (2012). Making sense of the newspaper crisis: A critical assessment of existing research and an agenda for future work. New Media and Society, 14(8), 1375-1394.

Soley, L. C., \& Craig, R. L. (1992). Advertising pressures on newspapers: A survey. Journal of Advertising, 21(4), $1-10$.

Svensson, E.-M. (2016). Upholding the legislation between editorial and commercial content in legislation and self-regulation. In M. Edström, A. T. Kenyon, \& E.M. Svensson (Eds.), Blurring the lines (pp. 109-119). Göteborg: Nordicom.

Swiss Media. (2016). Code of conduct. Retrieved from http://www.schweizermedien.ch/getattachment/Me dien/Code-of-Conduct/Code_of_Coduct_Unterzeich net.pdf.aspx

Underwood, D. (1993). When MBAs rule the newsroom. New York, NY: Columbia University Press.

\section{About the Author}

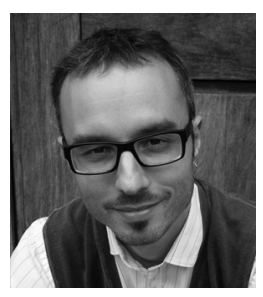

Colin Porlezza, PhD, is a Senior Research and Teaching Associate at the Institute of Mass Communication and Media Research (IPMZ), University of Zurich, Switzerland. Before that he was Lecturer in Journalism at the Department of Journalism at City, University of London, UK. His research interests are journalism innovation, data journalism and media accountability. 